\title{
TPS as an Effective Technique to Enhance the Students' Achievement on Writing Descriptive Text
}

\author{
M. Pd. Sumarsih ${ }^{1} \&$ Dedi Sanjaya ${ }^{1,2}$ \\ ${ }^{1}$ English and Literature Department, Faculty of Languages and Arts, Universitas Negeri Medan, Indonesia \\ ${ }^{2}$ English Applied Linguistic Program, College of Arts and Sciences, Universiti Utara Malaysia, Malaysia \\ Correspondence: M. Pd. Sumarsih, English and Literature Department, Faculty of Languages and Arts, \\ Universitas Negeri Medan, Jl. Willem Iskandar Pasar V - Kotak Pos No. 1589 - Medan 20221, Indonesia. Tel: \\ 62-812-604-7395. E-mail: isih58@yahoo.com
}

Received: June 7, 2013 Accepted: October 18, 2013 Online Published: November 5, 2013

doi:10.5539/elt.v6n12p106 URL: http://dx.doi.org/10.5539/elt.v6n12p106

\begin{abstract}
Students' achievement in writing descriptive text is very low, in this study Think Pair Share (TPS) is applied to solve the problem. Action research is conducted for the result. Additionally, qualitative and quantitative techniques are applied in this research. The subject of this research is grade VIII in Junior High School in Indonesia. From this study, the mean of the first evaluation sharply increased to the mean of the second evaluation and to the mean of the third evaluation. They are $66.4375,78.125$ and 87.5625 respectively. Observation result showed that the students gave their good attitudes and responses during teaching and learning process by applying the application of TPS (Think Pair Share) technique. Questionnaire and interview report showed that students agree with the application of TPS (Think Pair Share) technique have helped them in writing descriptive text. It can be conclude that the students' achievement is improved when they are taught by TPS Technique.
\end{abstract}

Keywords: writing, descriptive text, achievement, think pair share

\section{Introduction}

\subsection{Background}

English is the language of global terms that need to be developed in Indonesia. Due to the ability to speak English, people is able to obtain and provide information that is very important to develop oneself and the environment. Therefore, in Indonesia Language has been incorporated into the curriculum of English schools and colleges so that English can be taught to the Indonesian learners well.

In learning the English language, there are four skills should be taught to students. They are speaking, listening, reading and writing. In practice, learning the lessons taught writing after speaking, listening and reading. But this does not state that learning writing is not important. In fact, writing is a very important lesson learning that is why writing is taught after the third important element is taught and writing also is the very difficult subject for the students. It is related to Oshima and Hogue (1999:3) that writing, particularly academic writing is not easy. It takes study and practice to develop this skill. For both native speaker and new learners of English, it is necessary to note that writing is a process, not a "product". It means that a piece of writing, whether it is a composition for your English class or a lab report for your chemistry class is never complete; that is, it is always possible to review and revise, and review and revise again.

Writing is a very essential capability for being mastered by students; writing is also an excellent communication tool. Through writing, each person is able to convey feelings, ideas, and announcements to others. Sharples (1999:8) actually, writing is an opportunity; it allows students to express something about themselves, explore and explain ideas. Student can convey their ideas in their mind by organizing them into a good text so that the others easily know them and they can think critically. Therefore, learning is very significant to improve writing skill in particular learning of English in Indonesia because the writing is a process of transformation of thoughts and ideas into tangible forms of writing. In addition, many people choose writing as a means of effective and efficient communication of information to be conveyed in some ways like posting letters, business letters and important information in a company's product. 
From previous elaboration, the descriptive text is one genre that must be mastered by students in learning English. And theoretically, according to Evawina (2010:7) descriptive paragraph is a paragraph vividly portrays a person, place, or thing in such a way that the reader can visualize the topic and enter into the writer's experience.

In fact, not all students are able to write descriptive paragraph properly and in accordance with the existing elements in the descriptive text. Based on the researcher's observation at the time of the teaching practice program contained $75 \%$ of students who were unable to write a descriptive paragraph. Teachers of English have already taught the topic to students well but the students still had the problem in writing descriptive text. In addition, the researcher also had looked the teachers of English language teaching by lecture, and then asked the students to write descriptive paragraph individually. Surprisingly, student's ability to write descriptive paragraph were very less because the learning technique that is adopted by teachers of English language is a technique that does not fit anymore in this day because it reduce the interest and liveliness of the students in the learning process so that students are bored and do not want to continue learning as they ought to do.

At this present time, there are already implementations Learning Revolution in teaching and learning is no longer centered on teachers. In other words, it is called "TCL" but it has been centered on students. It is called "SCL" theoretically SCL is an approach to education focusing on the needs of the students, rather than those of others involved in the educational process, such as teacher and administrators. So the teacher is only as facilitator and a provider of solutions in learning is no longer merely as a source of knowledge in the learning process.

Forthermore, the researcher offer a technique that have to be applied in the learning process of writing descriptive paragraph because Ransdell and Laure Barbier (2002: 143) maintained that a good writing strategy can be trained, and it can improve writing performance. The technique is the implementation of Student Centered Learning (SCL) and the development of Cooperative Learning (CL) that according to Slavin (1995:2) Cooperative Learning refers to variety of teaching techniques in which students work in small group to help one another learn academic content. In cooperative classrooms, students are expected to help each other to discuss and argue with each other, to assess each other's current knowledge and fill in gaps in each other's understanding, so that the interest and active students in the learning process can be improved not only individually but also in groups. Learning technique which the researcher refers to is Think Pair Share (TPS).

Think Pair Share (TPS) is one of the Cooperative Learning techniques which poses a challenging or open-ended question and gives students a half to one minute to think about the question. Students then pair with a collaborative group member or neighbor sitting nearby and discuss their ideas about the question for several minutes. Furthermore, Lyman Proposed Think Pair Share (TPS) in 1981. She stated that TPS is short collaborative learning structure and minimum risk, in addition is appropriate technique for teachers and learners who are beginner to collaborative learning (www.wcer.wisc.edu). It is designed to motivate the students to tackle and succeed at problem which initially beyond their ability. It is based on the simple nation of mediated learning. Obviously, one alternative to solve the problem of writing descriptive paragraph is by applying TPS. With the application of this technique is expected to enhance students' skills in writing descriptive paragraph properly and in accordance with the existing elements in the descriptive paragraph.

\subsection{Research Question}

Based on the background of the study, the problem of this study is formulated as follows:

"Is the students' achievement on writing descriptive Text significantly enhance while they are taught through Think Pair Share Technique?"

\subsection{Scope}

There are many genres on writing subject in Junior High School such as recount, narrative, procedure, descriptive, and etcetera. Specipically this study focused on improving on the students' achievement on writing descriptive text. The technique that is used to improve students' achievement on writing descriptive paragraph is TPS technique. In other words, the study is concentrated on the genre of descriptive.

\subsection{Objective}

In relation to the problem, the objective of the study is to investigate and to find out the improvement of students achievement in writing descriptive text through the application of Think Pair Share (TPS) technique.

\subsection{Significant}

Finding of this study is expected:

1) to motivate the students to be better on writing descriptive paragraph, 
2) to provide significant information for the English teacher in their attempt to decide the TPS in teaching descriptive writing in senior high school,

3 ) to increase the readers knowledge about TPS and descriptive paragraph and,

4) to help the next researcher candidate of the teacher to apply a model in teaching learning process.

\section{Literature Review}

\subsection{Achievement}

Travers (1970:447) states that achievement is the result of what an individual has learned from some education experience. Additionally, Yelon, Weinstein, and Weener (1977:301) express achievement as the successfulness of individual, while another source Smith and Hudgins (1964:95) says that achievement is to do one's best, to be successful to accomplish tasks requiring skill and effort and to be recognized by authority.

Completely, achievement is the result, the successfulness, the extent or ability, the progress in learning education experiences that the individual indicates relation with his/her educational learning. Achievement concerns with what someone has actually learnt whereas aptitude is the potential for learning something. In other words, achievement is a success in reaching particular goal/status or standard, especially by effort, skill, courage, and so on.

\subsection{Writing}

Writing is a process of formulating and organizing ideas in right words to deliver the aim and present them on a piece of paper. According to Jones in R. Cooper and Odell (1977:33) writing is synonymous with discourse, and discourse is discussed in terms of its aims, it relate to the function of language, and in terms of its feature, which are the separate elements, devices, and mechanism of language.

On the other hand, Reinking, Hard and Osten (1993:188) state that writing is a way of communication and of course communicates all the time. And then Deporter and Heracki (2002:179) explain that writing is a whole brain activity, which use bright brain side (emotion) and left-brain side (logic). Although right and left-brain sides are used in writing, right brain side has a big position because it is a place, which appears new ideas and emotion. To state that, writing is a whole brain activity to formulate and organize ideas in right words to deliver and communicate the aims to the reader and present it on a piece of paper.

\subsection{Descriptive Text}

A descriptive text is a piece of writing that is intended to convey meaning to the reader through sensory details and provides image to the reader (http://www.ehow.com). Additionally, descriptive text is a paragraph may be defined as a group of sentences that are closely related in thought and which serve one comment purpose often used to describe what a person looks like and acts like, what a place looks like, and what an object looks like. Furthermore, Pardiyono (2007:34) state that description paragraph is a type of written text paragraph, in which has the specific function to describe about an object (living or non-living things) and it has the aim that is giving description of the object to the reader clearly.

From the previous definition, it can be maintained that descriptive paragraph is a paragraph that describes a particular person, place or event in great deal. Descriptive writing vividly portrays a person, place, or things in such a way that the reader can visualize the topic and enter into the writer's experience. It is a way to enrich others forms of writing or as a dominant strategy for developing a picture of what something looks like.

Furthermore, Jolly (1984:470) asserts there are five types of descriptive writing paragraph. They are:

\section{a. Describing Process}

Describing a process not only explains how something is done, but also explains why it is done and what is needed to complete the process.

b. Describing and event

To describe an event, a writer should be able to memorize and remember what happened in the event. Supposed the writer will write about Tsunami that is happened in Japan. In this case, he / she has to explain all details related to the event, so that the readers can imagine the real situation and condition.

c. Describing a personality

In describing a person, the first thing that we do is recognizing his/her individual characteristic. We need to describe people occurs fairly areas of physical attribute (hair, eyes), emotional (warm, nervous), moral attributes (greedy, honest, worthy, trust), and intellectual (cleverness, perception) 


\section{d. Describing a place}

Presenting something concrete is the way to describe place, for example: a home, a hospital, and school.

e. Describing an object

To describe an object accurately is done by providing the physical characteristic of the object such as the color, form, shape, and so on.

\subsection{Part of Descriptive Text}

There are three part of descriptive text as Pardiyono (2007:34) maintain that three parts of descriptive, they are (1) communicative purpose, that is to describe an object (human and non-human), (2) rhetorical structure, there are two parts of rhetorical structure a) identification, that is statement that consist of one topic to describe; b) description, that is consist of the detail description about object that identify in identification, and (3) grammatical patterns, it is needed to understand that in descriptive paragraph, declarative sentence is used and using present forms.

\subsection{Think Pair Share (TPS)}

The think, pair, share strategy is a cooperative learning technique that encourages individual participation and is applicable across all grade levels and class sizes. Students think through questions using three interesting parts:

1) Think: Students think independently about the question that has been posed, forming ideas of their own.

2) Pair: Students are grouped in pairs to discuss their thoughts. This step allows students to articulate their ideas and to consider those of others.

3) Share: Student pairs share their ideas with a larger group, such as the whole class. Often, students are more comfortable presenting ideas to a group with the support of a partner. In addition, students' ideas have become more refined through this three-step process (www.teachervision.fen.com).

On the other hand, Think-Pair-Share is a strategy designed to provide students with "food for thought" on a given topics enabling them to formulate individual ideas and share these ideas with another student. It is a learning strategy developed to encourage student classroom participation. Rather than using a basic recitation technique in which a teacher poses a question and one student offers a response, Think-Pair-Share encourages a high degree of pupil response and can help keep students on task.

\subsection{The Steps of Think Pair Share}

1) With students seated in teams of 4 , have them number them from 1 to 4 .

2) Announce a discussion topic or problem to solve. (Example: Which room in our school is larger, the cafeteria or the gymnasium? How could we find out the answer?)

3) Give students at least 10 seconds of think time to THINK of their own answer. (Research shows that the quality of student responses goes up significantly when you allow "think time.")

4) Using student numbers, announce discussion partners. (Example: For this discussion, Student \#1 and \#2 is partners. At the same time, Student \#3 and \#4 will talk over their ideas.)

5) Ask students to PAIR with their partner to discuss the topic or solution.

6) Finally, randomly call on a few students to SHARE their ideas with the class.

Teachers may also ask students to write or diagram their responses while doing the Think-Pair-Share activity. Think, Pair, Share helps students develop conceptual understanding of a topic, develop the ability to filter information and draw conclusions, and develop the ability to consider other points of view.

\section{Methodology}

This research is conducted as an action research procedure since involved a substantive act with a research procedure to find the improvement. Stringer (2007:1) maintains that action research is systematic approach for investigation that enables people to find effective solutions for the problems they confront in their everyday life. Action research focused on specific situations and localized solutions. Action research provided the means by which people in schools, business and community organizations; teachers; and health and human services may increase the effectiveness of the work in which they are engaged

In this research, the data is collected by quantitative and qualitative approach. Quantitative data is collected with administrating composition text and qualitative is one research technique that is describing the situation and the event (Sugyono, 2004:4). 
Quantitative data is collected through evaluation sheet, which is administrated by the researcher. For gathering the qualitative data, the researcher used observation sheet, interview sheet and questionnaire. Observation sheet is used to identify all the condition that happened during the teaching learning process including teacher, students and the context of situation that were done by the collaborator, interview sheet is used when the writer want to identify the problems occurred in the learning process and questionnaire as the personal records which usually taken by the writer that is written up daily.

A collaborator is asked to observe and evaluate all the situations during the teaching learning process, the researcher, the students and the class in the teaching learning process.

\section{Result and Discussion}

The students' score increased from first evaluation to third evaluation. The writer gave the evaluation in second, fourth, and six meeting. During the research, it is found out that the students' score kept improving from first evaluation to last evaluation. By application TPS the students' score is significantly improved. The ranges of score improvement can be seen in the following table:

Table 1. Range of score improvement

\begin{tabular}{|c|c|c|}
\hline Range of Score Improvement & Students' Initial & Total \\
\hline $26-36$ & & 7 \\
\hline $21-25$ & & 8 \\
\hline $16-20$ & & 9 \\
\hline $11-15$ & & 5 \\
\hline $6-10$ & & 3 \\
\hline Number of Students & & 32 \\
\hline
\end{tabular}

There are 7 students who got the improvement of score 26-30. They were students who did not like English. But, after the teacher paid attention to them more, asked their problem, and applied TPS Technique, they became interested in writing descriptive text. And then 8 students who got the improvement of score 21-25. They were active students during teaching learning process. Almost of them got points 87 up in the last evaluation. They were active from the first until the last meeting in asking questions and they discussed every problem that they faced with their own team and pair so that their scores also kept improving. Furthermore, 9 students who got the improvement of score 16-20. Even though the improvement does not increase dramatically, it does not mean the students in this range are not competent in writing descriptive text. Two of them achieved satisfying score up to 90. Then the low score in this range is just 83 , it means they pass the test well. Surprisingly, there are 5 students who got the improvement of the score 11-15. The score improvement is not too high almost students in this range are smart students. Unfortunately, There is one student who got the score just 75 in the last evaluation even though this learner still pass the evaluation since they were very smart students but they did not much pay attention to the teacher and in their own team, they were not serious to hear the explanation. But, they kept improve their score until the last writing evaluation because of the TPS technique. Next, there are 3 students who got the improvement of score 6-10. The score improvement is quite low, but in these range no one got lower than 80. It means they are good students but they did not pay attention to the lesson that is given by the teacher.

There are differences in the lowest and the highest of students' writing score in each writing evaluation, which is given during the research. The differences show that there is a significant improvement of students' writing. The improvement of students' score in each writing evaluation can be seen in the following table:

Table 2. Comparison of students' score on writing descriptive text during the three evaluations

\begin{tabular}{cccc}
\hline Type of Score & $\begin{array}{c}\text { Evaluation I } \\
\text { M1 }\end{array}$ & $\begin{array}{c}\text { Evaluation II } \\
\text { M4 }\end{array}$ & $\begin{array}{c}\text { Evaluation III } \\
\text { M6 } \\
\text { Cycle II }\end{array}$ \\
\hline Lowest Score & 60 & & 70 \\
Highest Score & 80 & 85 & 75 \\
\hline $\mathrm{N}$ & 32 & 32 & 90 \\
\hline
\end{tabular}

Note: $\mathrm{M}=$ Meeting $\mathrm{N}=$ Number of Students 
From the table 2, it is seen that students' score kept improving. In writing evaluation I, the lowest score is 60 and the highest score is 80 . In writing Evaluation II, the lowest score is 70 and the highest score is 85 whereas in the last writing evaluation, the lowest score is 75 and the highest score is 90 . It shows the significant improvement in students' writing descriptive text.

The improvement of students' score in writing descriptive text through TPS also can be seen from the mean of the students' score in every writing evaluation. The mean of students' score can be seen below:

1) $\mathrm{X}=2126 / 32 * 100 \%=6643.75 \%$

$\mathrm{X}=2500 / 32 * 100 \%=7812.5 \%$

$\mathrm{X}=2802 / 32 * 100 \%=8756.25 \%$

Table 3. The improvement of mean scores of students' writing

\begin{tabular}{llll}
\hline Meeting & & Total Score & Mean \\
\hline Evaluation I (Cycle I) & I & 2126 & 66.4375 \\
Evaluation II (Cycle I) & II & 2500 & 78.125 \\
Evaluation III (Cycle II) & III & 2802 & 87.5625 \\
\hline
\end{tabular}

The mean of the students' score in the first meeting is the lowest of all meetings. In the last meeting, the students' score improved. From the data analysis, the mean score of the students' writing increased from 66.4375 to 87.5635 . It means that the ability of students in writing descriptive text is improved.

In this research, the indicator of successful in writing descriptive text is if $75 \%$ of students have got score up to 75 in their writing evaluation because the English passing grade at the school is 75 . The number of the students who were competent in writing descriptive text is calculated below:

2) $\mathrm{P} 1=2 / 32 * 100 \%=6.25 \%$

$\mathrm{P} 1=26 / 32 * 100 \%=81.25 \%$

$\mathrm{P} 1=32 / 32 * 100 \%=100 \%$

Table 4. The percentage of students' writing descriptive text

\begin{tabular}{lllll}
\hline Evaluation & Cycle & Meeting & Students who got score 75 up & Percentage \\
\hline I & I & I & 2 & $6.25 \%$ \\
II & I & IV & 26 & $81.25 \%$ \\
III & II & VI & 32 & $100 \%$ \\
\hline
\end{tabular}

In writing evaluation I, there are 2 students who got point 75 up. The percentage of students' achievement in descriptive text kept increasing when TPS technique is applied. In the first cycle, $6.25 \%$ students got points 75 up whereas in the second cycle 100\% students who got points 75 up. The range of the first meeting $(6.25 \%)$ and the last meeting (100\%) is $93.75 \%$. It has been proved that $93.75 \%$ students got the good score on their writing achievement. It can be stated that TPS technique works effectively and efficiently in helping students in improving their achievement in writing descriptive text.

\subsection{Qualitative Data}

The qualitative data are taken from observation sheet, questionnaire sheet and interview that gained within two cycles.

\subsubsection{Observation Sheet}

From the result of observation sheet, it can be concluded that teaching learning process by applying TPS technique run well. The situation of teaching learning process is comfort, lively, and enjoyable. Because from the data that is taken from the first (I) meeting to the last (VI) meeting we can find out that the Note in the data got good and very good. It means the score in this data is just gotten from 3 to 4. 
So this TPS technique created a good environment in teaching learning writing in which students became active in the process of writing, focus their mind to the teachers' explanation, and share in their team and pair and then finish in individually. In individually work, the students could improve their confidence to finish the work because they had discussed in team and pair.

\subsubsection{Interview}

From the interview data those were taken by the teacher and the students from the first meeting and the last meeting, we found out that the teacher is very interesting to the students because the students were very active and enjoyed with English but students ability in writing descriptive text is not good enough and then the teacher does not have effort to improve it.

From the interview with the students in the first meeting, it can be found out that the students very interesting with English and most of the students like to write descriptive text, because from 6 students that the writer interviewed said like. So from this data we can conclude that most of the students like to write the descriptive text. That is why it is needed to improve their achievement in writing descriptive text by the application of TPS.

From the second interview that was taken from teacher, it can be find out that the application of TPS in teaching learning process especially in writing descriptive text is very helpful to improve the ability of students in writing descriptive text. And according to the teacher this technique is very good because can make the students became active and enjoy the lesson.

Furthermore, from the last interview that is taken from the students it can be find out that most of the students like this technique and the said that this technique is very good to improve their achievement in writing descriptive text because they could be active and enjoy the material. And from the 6 students, all of them said TPS is very good and just one student said that it is very busy but the student also like.

So, from the entire interview, TPS technique is very appropriate to improve the students' achievement on writing descriptive text, and hopefully the teacher will try to apply TPS in teaching learning process not only on writing but also on another skill.

\subsubsection{Questionnaire}

From the result of questionnaire, it is found out that TPS technique can enhance the achievement of students because from the data no one of the students fill in disagree and strongly disagree then no more than 4 students fill in the neutral. Very good thing is that, most of the learners fill in agree and strongly agree. It means that this TPS technique is very suitable for the students.

In significantly, from the data that is taken from questionnaire sheet I we could account that from the statement 1 until statement 8 , the percentage of strongly agree is 331 with mean $41.40625 \%$, agree $431.25 \%$ with mean $53.90625 \%$, neutral $37.5 \%$ with mean $4.6875 \%$ and disagree and strongly disagree $0 \%$. So, from this questionnaire data we can conclude that the students is very interested and enjoy the TPS technique in teaching learning process especially in writing descriptive text.

Besides that, from the data that is taken from the questionnaire sheet 2 it can be found in the first statement that the percentage of students who choose a is $71.875 \%, \mathrm{~b}$ is $3.125 \%, \mathrm{c}$ is $25 \%$ and $\mathrm{d}$ is $9.375 \%$. It means that most of students had learned to work to gather from this TPS technique. So they were active in that teaching learning process. And then from the statement 2 the students who choose a is $43.75 \%, \mathrm{~b}$ is $28.125 \%$, c is $15.625 \%$ and $\mathrm{d}$ is $12.5 \%$. It meant that most of students had learned about pair accountability and pair responsibility. In additional, from the statement 3 the students who choose a is $84,375 \%, b$ is $6.25 \%$, c is $6.25 \%$ and $d$ is $3.125 \%$. It means that most of students in this research had learned to produce something alone.

From the all questionnaire data, it can be concluded that the students were very interested on the TPS technique and they do not only improve their achievement in writing descriptive text but also improve their teamwork, responsibility and self-confidence.

\section{Conclusion and Suggestion}

\subsection{Conclusion}

Having analyzed the data that have been presented in the previous elaboration, it is found that average scores of students in every evaluation kept improving. It can be said that there is a significant improvement on the students' achievement in writing descriptive text by applying the application of Think Pair Share technique. It can be seen from the improvement of mean of students' score. The score continuously improved from the first evaluation to the third evaluation. They are $66.4375,78.125$ and 87.5625 respectively. Observation result showed that the students gave their good attitudes and responses during teaching and learning process by applying the 
application of TPS (Think Pair Share) technique. Questionnaire and interview report showed that students agree that the application of TPS (Think Pair Share) technique had helped them in writing descriptive text. Certainly, the application of TPS technique is significantly improved students' achievement in writing descriptive text.

\subsection{Suggestion}

The result of this study shows that the application of TPS technique can essentially improve students' achievement in writing descriptive text. In relation to the conclusion, some points are suggested, as follow:

1) The English teachers are suggested to apply TPS (Think Pair Share) technique as teaching technique to stimulate the students' learning writing spirit in teaching writing process.

2) For the readers who are interested for further study related to this research should explore the knowledge to enlarge the understanding about how to improve students' achievement in writing and search another reference.

\section{References}

Deporter, B., \& Heracky, M. (2002). Quantum Learning. Bandung: Penerbit Kaifa.

Evawina, E. (2010). Thesis of Improving Students' Achievement on Writing Descriptive Paragraph through the Application of Student Team Achievement Division. Medan: State University of Medan.

Pardiyono. (2007). Pasti Bisa! Teaching Genre Based Writing. Yogyakarta: CV. Andi Offset.

Mulyasa, E. (2006). Kurikulum Tingkat Satuan Pendidikan. Bandung: Remaja Rosdakarya Offset Bandung.

Oshima, A., \& Hogue. (1999). Writing Academic English (3rd ed.). United State of America: Addison Wesley Publishing Company.

Ransdell, Sarah., \& Marie-Laure, B. (2002). New Direction for Research in L2 Writing: Studies in Writing. Dordrecht: Kluwer Academic Publisher.

Reinking, Hart A., \& Osten, R. (1993). Strategies for Successful Writing: Rhetoric, Reader and Handbook. New Jersey: Prentice Hall.

Sharples, M. (1999). How We Write: Writing as Creative Design. London: Routledge.

Slavin, E. Robert. (1995). Cooperative Learning Theory: Research and Practice. New York: The Hopkins University.

Stringer, Ernest T. (2007). Action Research (3rd ed.). United State of America: Sage Publication Inc.

Travers, John P. (1970). Fundamental of Educational Psychology. Scranton, Pennsylvania: International Textbook Company.

About Descriptive Paragraph. (2013, June 05). In eHow. Retrieved June 06, 2013, from http://www.ehow.com/about_4740909_decriptive-paragraph.html

Think Pair Share Cooperative Learning Strategy. (2013, June 8). In Teacher Version. Retrieved June 9, 2013, from http://teacherversion.fen.com/group-work/cooperative-learning/48547.html

Think Pair Share. (2013, June 8). In Doing CL. Retrieved June 9, 2013, from http://www.wcer.wisc.edu/archive/cl1/cl/doingcl/thinkps.html

\section{Copyrights}

Copyright for this article is retained by the author(s), with first publication rights granted to the journal.

This is an open-access article distributed under the terms and conditions of the Creative Commons Attribution license (http://creativecommons.org/licenses/by/3.0/). 